\title{
Anatomy of Pneumatophore of Mauritia vinifera Mart
}

\author{
Luiz Alfredo Rodrigues Pereira ${ }^{1}$, Maria Elisa Ribeiro Calbo ${ }^{1 *}$ \& Claiton Juvenir Ferreira ${ }^{2}$ \\ ${ }^{1 *}$ Dept of Botany, University of Brasília. ${ }^{2}$ Undergraduate student, Biological Sciences, University of Brasilia, \\ 70910-900, Brasilia-DF, Brazil
}

\begin{abstract}
Pneumatophores of Mauritia vinifera Mart. were collected from six month-old plants maintained submerged in fresh water to induce pneumatophore formation. Twenty day-old pneumatophores had a quite prominent root cap. The epidermis was composed of hexagonal cells, tangentially distributed along the cylindric surface of the organ. In transverse section these pneumatophores had a simple epidermis over several layers of sclerified parenchyma, which covered an aerenchyma with large intercellular spaces. The endodermal cells had Casparian strips. The vascular cylinder was polyarch, with a pith and surrounded by a unisseriate pericycle. Anatomically the 4 monthold pneumatophores were similar to the younger ones, except for the absence of the epidermis. The epidermis is replaced by a protective tissue, whose lignified and suberized cells projected themselves outwards, giving it a filamentous aspect. There was no accumulation of starch or tannins in the pneumatophores, except for the presence of statoliths in the root cap. No lenticels were observed in pneumatophores of $\mathrm{M}$. vinifera. The main function of the pneumatophores of M. vinifera is to allow gas exchange, facilitating the supply of oxygen to the submerged root portions.
\end{abstract}

Key words: buriti; Mauritia vinifera; pneumatophores; gas exchange.

\section{INTRODUCTION}

Mauritia vinifera Mart., or buriti, is a palm tree that reaches more than $15 \mathrm{~m}$ in height, with palmate erect leaves, whose stem diameter is around $50 \mathrm{~cm}$ when adult. The palm is widely used for crafting objects such as nets and strings, in production of foods and beverages (sweets, buriti wine, etc.), in animal feed and wood for construction of rural bridges. The buriti occurs in the states of Bahia, Minas Gerais, Mato Grosso, Goiás, Ceará and Maranhão (Calbo, 1996). The usual habitat of buriti is acid soil slopes (Cavalcante, 1974) and palustre environments as swamps or veredas (Paula \& Abreu, 1997). This suggests that this species have developed morphological and physiological adaptations to tolerate flooded conditions (Calbo, 1996).

When plants suffer $\mathrm{O}_{2}$ deficit they can respond through several types of adaptations, including morpho-anatomical or physiological changes which facilitate their survival. Stagnant water is usually poor in oxygen, due to its low $\mathrm{O}_{2}$ diffusion coefficient and metabolic activity of microrganisms. In addition, the roots themselves were organs that respire intensely; therefore they have a great demand for $\mathrm{O}_{2}$. Consequently flooded soils can lead the root to conditions of hypoxia which hinder aerobic respiration. Morphological and anatomical changes were usually essential for survival.

Different types of adaptations could be observed in different plants, such as formation in the submerged organs of a tissue with large internal cavities, called aerenchyma, and formation of pneumatophores (Fahn, 1982). The pneumatophores were a special type of root with negative geotropism that project above the water surface or the level of flooded soils (Esau, 1977). In contact with air these roots develop lenticels, which improve gas exchange between roots and environment (Hook, 1984). In swamps and wetlands the presence of pneumatophores and aerenchyma facilitates oxygen diffusion through the tissues, maintaining levels adequate for cellular respiration (Curran et al., 1986; Gill, 1970).

Many studies had been carried out using mangroves as models. However, these were not the only plants capable of developing pneumatophores. Thus, it is important to broaden our knowledge about this theme using other pneumatophore-forming species such as buriti. We

Author for correspondece 
had not found references to pneumatophores in any other palms. The present study provides a morpho-anatomical description of pneumatophores induced in plants of Mauritia vinifera Mart. submitted to flooding.

\section{MATERIAL AND METHODS}

Six months old buriti plants, Mauritia vinifera Mart., were supplied by EMBRAPA-CPAC, Brasília -DF. The plants were placed in plastic buckets containing 18 liters of fresh water which completely covered the soil and root system. The buckets were covered with black plastic to prevent the development of green algae and consequently water oxygenation. Two to three weeks after flooding the pneumatophores began to appear in the root system of buriti plants. Two collections were made: the first at twenty days and the second four months after appearence of the first pneumatophores. Samples of pneumatophores were collected immediately above water level.

The pneumatophores were fixed in FAA 50 (Johansen 1940), then the material was dehydrated in a increasing alcoholic series and subsequently included in paraffin (Johansen, 1940; Sass, 1958). Transversal and longitudinal sections (12 to $20 \mu \mathrm{m}$ thick) were cut in a rotating microtome Leica RM 2145 and stained with safranine and fast green. The following histochemical tests were applied to fresh or fixed samples: lugol for starch, Phloroglucin $+\mathrm{HCl}(50 \%)$ to verify the presence of lignin in cell walls, ferric chloride for tannins and Sudan IV for cutin and substances of lipidic nature. The sections were photographed and drawn with a Zeiss photomicroscope Zeiss-Axioscop with a tube for image projection. Polarized light was used to identify the presence of birefringent structures.

For scanning electron microscopy, the pneumatophores were fixed in glutaraldehyde (2\%), prepared in cacodylate buffer $\mathrm{pH}$ 7.0. The plant material was dehydrated in acetone 50, 70, 90 and $100 \%(2 \mathrm{x})$. The pneumatophores were dried to critical point in $\mathrm{CO}_{2}$ using a Balzers $\mathrm{CPD}$ 030 device. Then the samples were covered with gold $(\mathrm{Au})$ in a Sputter Coater Balzers SCD 050. The observations were made in a scanning electron microscope JEOL - 840.

\section{RESULTS}

The 20 day-old pneumatophores of M. vinifera had a quite prominent root cap (Fig. 1). As the pneumatophore grew, parts of the root cap were released and small portions were left behind adhering to the main axis of the root. When the epidermis was observed from the outside, no intercellular spaces were seen in the hexagonal cellular lattice, and the largest axis of the cells was aligned with the organ circumference (Fig. 2,3). The pneumatophore of $M$. vinifera was a ramified structure composed of a large number of lateral roots (Fig. 3).

In transverse section the younger parts of pneumatophores had a simple epidermis (Fig. 4), whose external periclinal cell walls were slightly thicker than the others. Close to the epidermis, the cortex was formed by a sclerified parenchyma (Fig. 4), whose cells had the largest axis in the longitudinal direction, contrasting with the epidermal cells, whose largest axis was in the tangential plane (Fig. 3). This parenchyma consisted of three or four layers of cells (Fig. 5). The content of these parenchymatous cells reacted positively with Sudan IV, evidencing the presence of lipids inside the cell. An aerenchyma with large intercellular spaces was located next to the parenchyma; the aerenchyma cells formed structures like bridges between the external and internal regions of the cortex (Fig. 6). The endoderm was composed of non-lignified cells with primary cell walls with Casparian strips (Fig. 7). The central cylinder was a stele of the eustele type, formed by a unisseriate pericycle, and the vascular system was polyarch type (9-12 protoxylem poles) with a parenchymatous pith in the center (Fig. 8).

The 4 month-old pneumatophores resemble the 20 day-old structures, the only exception being the absence of epidermis in the older areas of the root. In these areas the epidermis was substituted by a protective tissue whose outermost layer of the tissue had cells that projected outwards, giving this tissue a filamentous aspect (Fig. 9, 10, 11). The cells of this protective tissue were parenchymatous, with the larger axis of the cell in the longitudinal direction of the root (Fig. 11). This tissue consisted of three or four layers of cells whose cell walls, even those that were projected, reacted positively with Sudan IV and phloroglucin, showing the presence of cutin and lignin in the 
wall. The presence of small ornamentations (Fig. 12) was also noticed. Accumulation of starch or tannins in the epidermis, cortex or vascular system of the pneumatophores was not observed; the only exception being the occurrence of statoliths in the root cap (Fig. 13).

In longitudinal sections the apex of the pneumatophores had a root cap that was formed by vacuolated cells: the external layers were friable, cells sloughing off easily (Fig. 13). Inside the root cap there were starch grains (statoliths) (Fig. 13). The apical meristem seemed to be constituted of three layers of initial cells plus one more external layer responsible for the formation of the root cap. Further studies of the promeristem were required for the confirmation of these data. Close to the apex of the root protoderm, procambium and the ground meristem could be identified (Fig. 13).

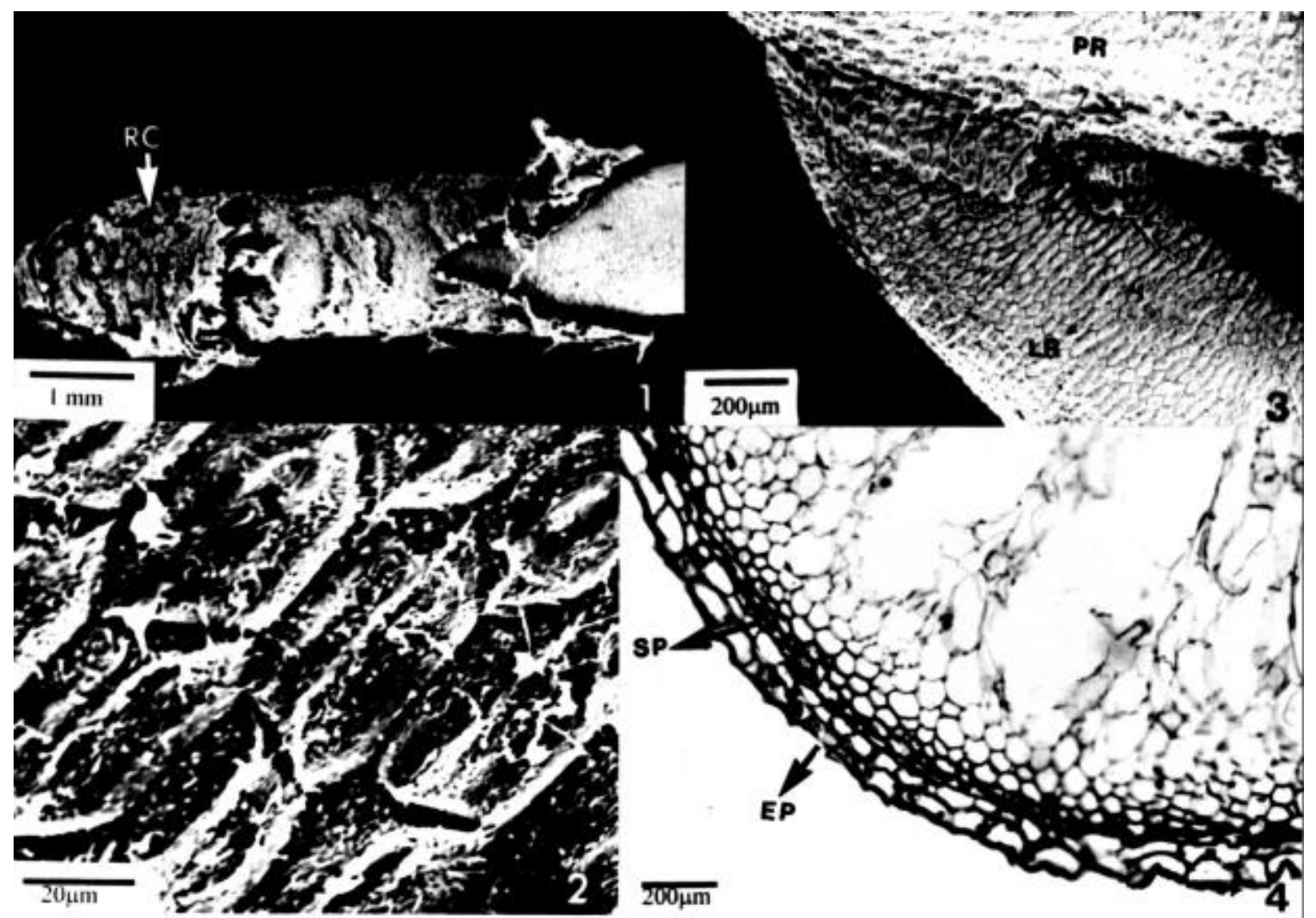

Figures 1-4 - Scanning electron micrographs showing aspects of 20-day old pneumatophores of M. vinifera. 1) The extremity of a pneumatophore; 2) Detail of the epidermis; 3) Detail of a lateral ramification; 4) Transverse section of a pneumatophore. (RC) Root cap; (PR) Principal root; (RL) Lateral root; (SP) Sclerified parenchyma; (EP) Epidermis.

\section{DISCUSSION}

The primary structure of pneumatophores of $M$. vinifera resembled with other monocotyledon roots. A well developed aerenchyma formed in the cortex. Through aerenchyma oxygen could diffuse in tissues and cells (Sorrel \& Dromgoole, 1988). In some plants (Littorella uniflora, Hydrocotyle umbellata) the diffusion of oxygen through aerenchyma was so efficient that it was compared with an oxygen pump (Waisel et al., 1991). Therefore, the presence of aerenchyma in pneumatophores could be related to the function of aeration in this type of root. The pneumatophore was defined as an aerial root projection, with negative geotropism, produced in swampy or marshy environments with the function of allowing gas exchange (Fahn, 1982). Thus, the presence of aerenchyma in these roots was directly related to the requirement of accumulation and 
supplying of $\mathrm{O}_{2}$ to the tissues. Esau (1977) supported this kind of function for aerenchyma, mainly related to plant tissues or organs that do not had direct access to the atmospheric air.

In $M$. vinifera, the existence of lignified and cutinized epidermis, besides three or four layers of sclerified parenchyma, whose cells also contained substances of lipidic nature, certainly imposed an additional barrier between the aerenchyma and the external environment, but it was not unsurmountable.

Lignin has been reported as substance constituted by phenylpropanoids (Brett \& Waldron, 1990; Wareing \& Phillips, 1981). It also impregnated cell walls of some kinds of plant cells such as fibers, vessel elements and as a component of some types of Casparian strips (Fahn, 1982). According to Brett \& Waldron (1990), the lignin molecule tended to fill all the spaces in the wall not occupied by macromolecules, which constituted an effective barrier to the penetration of several kinds of substances. A fully lignified cell wall led to the death the cell. Netheir epidermis nor the protective tissue were lignified enough to prevent all exchange of substances as seen by the low intensity of specific tests for lignin.

The cutin, which was formed by different types of saturated hydroxy-fatty acids forming a threedimensional polyester network (Martin \& Juniper 1970), was associated with the control of water loss by transpiration because of its presence in cuticles. However, the efficiency of the cuticle in avoiding water loss depended on its composition (Martin \& Juniper, 1970). Therefore, the cuticle, which had cutin, was not an absolute barrier to the loss of water, being, in determined atmospheric conditions, permeable to water-soluble materials (Martin \& Juniper, 1970). A similar phenomenon occured with respect to the diffusion of gases. Regardless of the fact that the cuticle was an obstacle to gas penetration (Brett \& Waldron, 1990; Martin \& Juniper, 1970), cuticles had a significant permeability to $\mathrm{CO}_{2}$ and presumably to other gases as well (Martin \& Juniper, 1970). Therefore, gases might also diffuse inside the organs from the external environment through the cuticle. Actually, it was known that $\mathrm{CO}_{2}$ diffused more easily than $\mathrm{O}_{2}$ and $\mathrm{N}_{2}$ (Martin \& Juniper, 1970). However, the concentration of $\mathrm{O}_{2}$ and $\mathrm{N}_{2}$ in the atmospheric air was much larger than that of $\mathrm{CO}_{2}$, which could provide the necessary pressure to permit entry through the cutinized and lignified cell walls. Even with closed stomata and cuticles considered highly impermeable, if the external $\mathrm{CO}_{2}$ concentration was artificially increased, $\mathrm{CO}_{2}$ assimilation through the cuticle increases proportionally (Martin \& Juniper, 1970). Consequently, gases such as $\mathrm{O}_{2}$ and $\mathrm{N}_{2}$ might pass through those cutinized cell walls and reach the internal space of pneumatophores.

M. vinifera four month-old pneumatophores lost their epidermis, exposing a parenchymatous protective tissue. This resulted in decrease of distance between aerenchyma and the external environment, which facilitated the entrance of air, and the thickness to be overcome was an important factor that affected the permeability to gases (Martin \& Juniper, 1970). The cells of the outermost layer of the parenchymatous protective tissue projected outwards outside (similar to trichomes or root hairs), which increased the surface of contact of this organ with the external environment, and consequently increased the area for the diffusion of gases from the exterior to the interior of the root. Trichomes are considered good sites of absorption, providing an important route of entry in leaves (Martin \& Juniper, 1970) and roots (root hairs). Consequently, those trichome-like structures could play the same role in pneumatophores of $M$. vinifera.

Ish-Shalon-Gordon \& Dubinsky (1992) suggested an interesting mechanism for the operation of the pneumatophores of Avicennia marina that perhaps could had a parallel in the pneumatophores of $M$ vinifera, although they do not form lenticels. The pneumatophores of A. marina developed lenticels in their periderm with complementary tissue inside their structure. These authors hypothesised that the presence of complementary cells, suberized and/or cutinized, with intercellular spaces would allow the free diffusion of air inside the root. Simultaneously, the existence of suberin and or cutin, which were hydrophobic substances, in the cell wall of complementary cells would avoid the entrance of water, during high tide, through the lenticels. If this happens it would result in the obstruction of air entering the pneumatophores. Thus, the outermost lignified or cutinized layers of cells in pneumatophores of $M$. vinifera could avoid the penetration excess of water inside the pneumatophores which would hinder their aeration. 


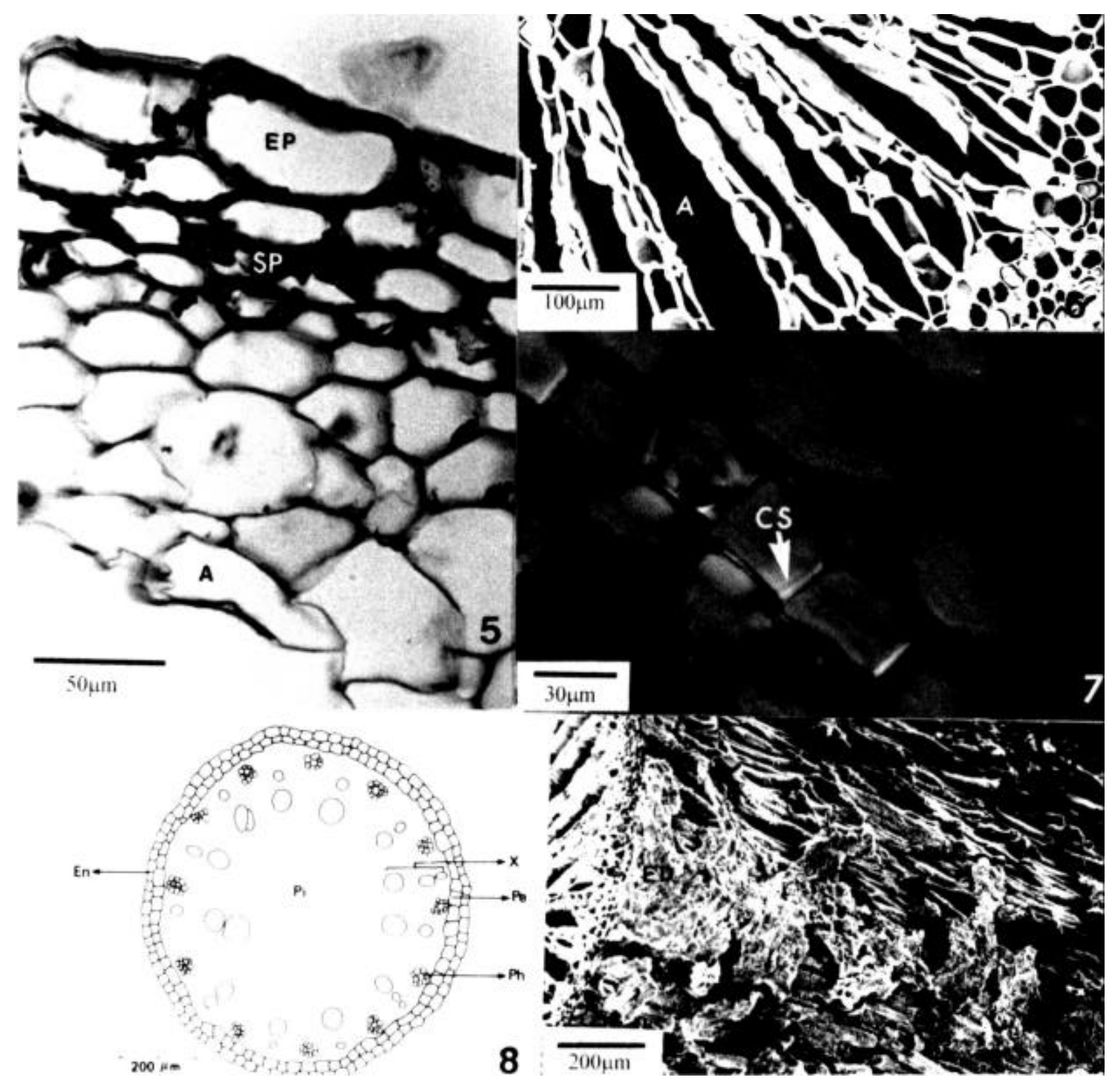

Figures 5 - 9. 5 - Details of transverse sections of pneumatophores of $M$. vinifera showing epidermis, sclerified parenchyma and aerenchyma. 6) Scanning electron micrograph of transverse section of the pneumatophore of $M$. vinifera showing the aerenchyma. 7) Micrograph in polarized light showing the endodermis with Casparian strips. 8) Schematic drawing of stele of the pneumatophore of $M$. vinifera. 9) Scanning electron micrograph showing the external surface of the pneumatophore of M. vinifera. (A) Aerenchyma; (CS) Casparian strips; (ED) Detaching epidermis; (En) Endodermis; (EP) Epidermis; (Pe) Pericycle; (Pi) Pith; (Ph) Phloem; (SP) Sclerified parenchyma; (X) Xylem. 


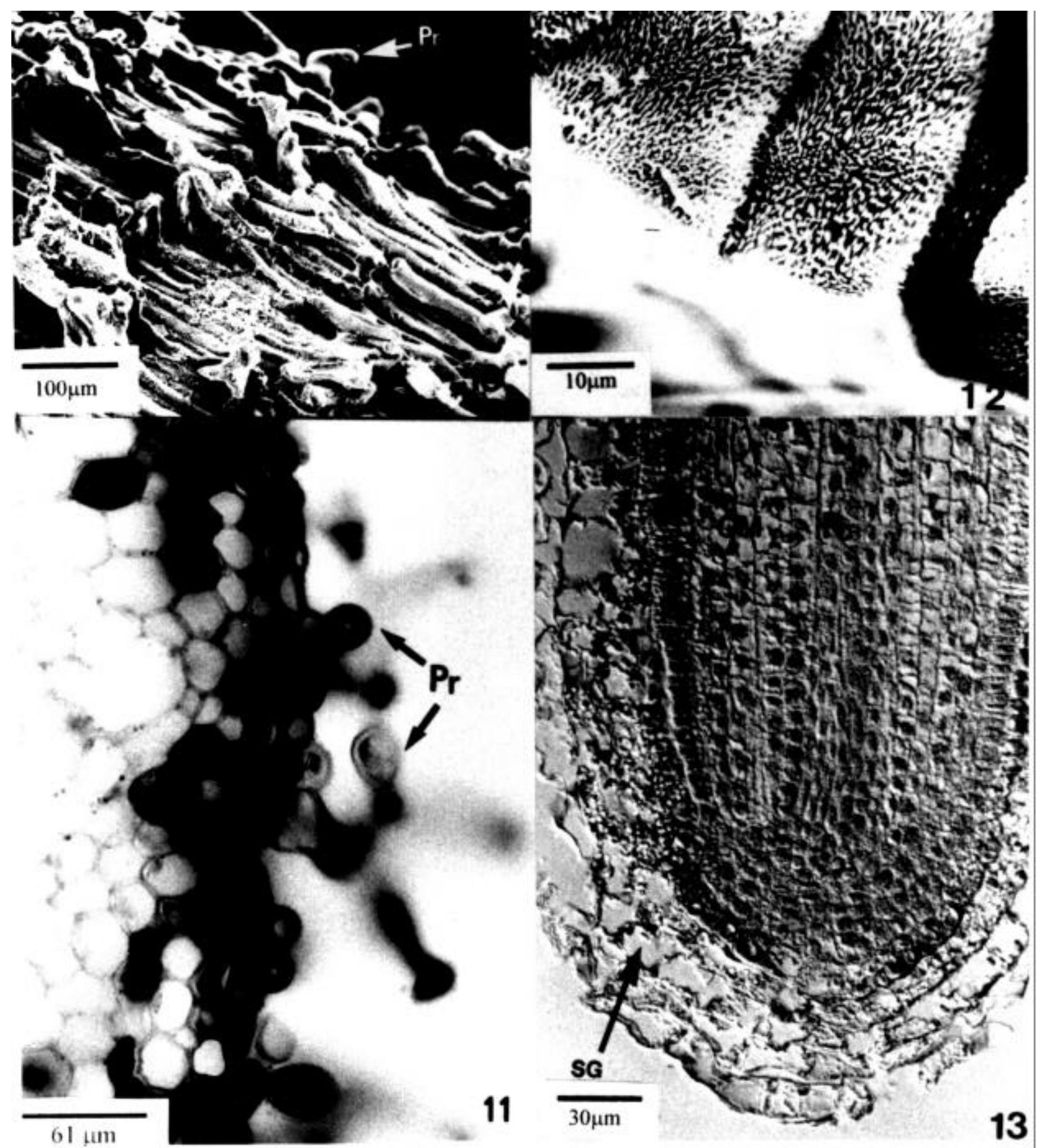

Figures 10 - 13. Strucutures of 4 month-old pneumatophores of $M$. vinifera. 10) Scanning electron micrograph of the surface of a 4 month-old pneumatophore showing the parenchymatous protective tissue whose cells project themselves outward. 11) Micrography of the transverse section of a pneumatophore showing the area of the protective tissue. 12) Details of the cells of the protective tissue showing the ornamented wall. 13) Pneumatophore apex showing the root cap with the statoliths (polarized light). (Pr) Projections of the cells; (Pc) Procambium; (GM) Ground meristem; (Pd) Protoderm; (SG) Starch grains.

Additional studies on the anatomy and morphology of the remaining root system of $M$. vinifera need to be undertaken to identify the function of each one of the parts (submerged parts and pneumatophores), integrating the whole system. In addition to this, physiological studies, 
such as the measurement of gas concentration, efficiency and the conditions of gas diffusion through the pneumatophores, need to be carried out.

\section{RESUMO}

Pneumatóforos de Mauritia vinifera Mart. foram coletados de plantas com seis meses de idade mantidas submersas em água com o objetivo de induzir a formação de pneumatóforos. Peumatóforos com 20 dias de idade possuem uma coifa bastante proeminente na raiz. A epiderme é composta de células hexagonais, tangencialmente distribuídas ao longo da superfície cilíndrica do orgão. Em seção transversal os pneumatóforos possuem epiderme simples. O córtex é formado por um parênquima esclerificado, um aerênquima com espaços grandes intercelulares e uma endoderme cujas células possuem estrias de Caspary. O cilindro vascular é poliarco, com medula e cercado por um periciclo unisseriado. Anatomicamente os pneumatóforos com 4 meses de idade são semelhantes aos com 20 dias de idade, sendo a única exceção a ausência da epiderme nos mais velhos. A epiderme é substituída por um tecido protetor lignificado cujas células são suberizadas e se projetaram fora dando um aspecto filamentoso a esse tecido. Não foi verificado acúmulo de taninos ou amido nos pneumatóforos, com exceção da presença de estólitos na coifa da raiz. Não houve formação de lenticelas nos pneumatóforos de $M$. vinifera estudados. A principal função dos pneumatóforos de $M$. vinifera é permitir trocas gasosas e ajudar no suprimento de oxigênio às porções subemersas da raiz.

\section{REFERENCES}

Brett, C. \& Waldron, K. (1990), Physiology and biochemistry of plant cell walls. Topics in plant physiology: 2. Series Editors: M. Black \& J. Chapman. Unwin Hyman. London.
Calbo, M. E. R. (1996), Trocas gasosas do açaí e buriti sob estresse de déficit de água e crescimento, porosidade e trocas gasosas do buriti sob inundação. Tese de doutorado. Universidade Federal de São Carlos (UFSCar), São.Paulo, Brasil.

Cavalcante, P. B. (1974), Frutas comestíveis da Amazônia II. Publicações avulsas do Instituto Nacional de Pesquisa da Amazônia - Museu Emílio Goeldi. $\mathrm{N}^{\mathrm{o}}$ 27. Belém - PA.

Curran, M; Allaway, W. G. \& Cole, M. (1986), Root aeration and respiration in young mangrove plants (Avicennia marina (Fosk) Vierh). Journal of Experimental Botany, 37:1225-1233.

Esau, K. (1977), Anatomy of seed plants. $2^{\text {nd }}$ ed. John Wiley \& Sons. New York.

Fahn, A. (1982), Plant anatomy. Pergamon International Library. New York.

Gill, C. J. (1970), The flooding tolerance of woody plants. Forest Abstract 31:671-678.

Hook, D. H. (1984), Adaptation to flooding with fresh water. In- Flooding and plant growth. Kozlowski, T. T. ed. San Diego, Academic Press, 1984. pp.265-269.

Ish-Shalon-Gordon \& Dubinsky, Z. (1992), Ultrastructure of the pneumatophores of the mangrove Avicennia marina. South African Journal of Botany, 58(5):358-362.

Johansen, D. S. (1940), Plant microtechnique. McGraw-Hill, New York \& London.

Martin, J. T. \& Juniper, B. E. (1970), The cuticles of plants. $1^{\text {st }}$ ed. Edward Arnold (Publishers) LTD. Great Britain.

Paula, J. E. \& Abreu, J. L. H. (1997), Madeiras nativas.. Fundação Mokiti Okada - MOA Brasília DF.

Sass, J. E. (1958), Botanical microtechnique. The Iowa State College Press. Iowa.

Sorrel, B. K. \& Dromgoole, F. I. (1988), Oxygen transport in submerged freshwater macrophyte Egeria densa Planch: role of lacunar gas pressures. Aquat. Bot 31:93-106.

Waisel, Y.; Eshel, A. \& Kafkafi, U. (1991), Plant roots. Marcel Dekker Inc. New York.

Wareing, P. F. \& Phillips, I. D. J. (1981), Growth and differentiation in plants. $3^{\text {rd }}$ ed. Pergamon Press. Oxford. 